\title{
ФАКТОР САНКЦИЙ \\ ВО ВНЕШНЕЭКОНОМИЧЕСКОМ СОТРУ ДНИЧЕСТВЕ ПРЕДПРИЯТИЙ ИРКУТСКОЙ ОБЛАСТИ: РИСКИ И ВОЗМОЖНОСТИ
}

В статье рассмотрено воздействие фактора санкционного давления на внешнеэкономическое сотрудничество Иркутской области. Выявлены основные риски и возможности выхода из кризисной ситуации. Автор приходит к выводу о «фантомности» санкционного давления, вызванного текущей внешнеполитической конъюнктурой.

Ключевые слова: санкции, Иркутская область, внешнеэкономическая деятельность, РУСАЛ, регион, политика, бизнес.

I. V. OLEYNIKOV

\section{THE SANCTIONS FACTOR IN FOREIGN ECONOMIC COOPERATION OF THE IRKUTSK REGION ENTERPRISES: RISKS AND OPPORTUNITIES}

The article describes the impact of the sanctions pressure factor on the foreign economic cooperation of the Irkutsk region. The main risks and opportunities of a way out of a crisis are revealed. The author comes to the conclusion about the "phantom" sanctions pressure caused by the current foreign policy situation.

Keywords: sanctions, Irkutsk region, foreign trade, RUSAL, region, politics, business. 
Начало 2018 г. было ознаменовано для внешнеэкономической деятельности экспортно-ориентированных предприятий Иркутской области негативным влиянием санкционной политики стран Запада, прежде всего США. Факторы экономического давления на глобальный российский капитал, оказывавшие с 2014 г. после начала событий на Украине влияние на крупный бизнес европейской части России, стали проявляться и в сердце Евразии - Восточной Сибири.

Соединенные Штаты Америки, пытаясь сохранить свое ускользающее влияние в современной международной системе, в которой активно заявляют о себе новые центры силы - такие как Россия, Китай и Индия, обращаются к своему традиционному инструменту влияния - политике экономического давления, торговым войнам. Однако использование такой стратегии в частично глобализированном мире чревато последствиями, отрицательными прежде всего собственно для крупного американского капитала, зависящего от экспорта сырья и продукции первого передела с территории различных государств, в том числе и из Российской Федерации.

Отметим, что периодически власти США объявляют о действии так называемых «новых санкционных списков», объясняя такой шаг тем, что российские бизнесмены получают прибыль от сотрудничества и поддержки российских властей. Так, в апреле 2018 г. под удар обновленных американских санкций попал «системный» российский олигарх Олег Дерипаска и аффрилированные с ним структуры - «РУСАЛ», «En + Group», основные производственные мощности которых расположены на территории Иркутской области - это ИркАЗ, БрАЗ, крупнейшие гидроэлектростанции Иркутской области и энергоугольные активы [5]. Россиянин попал в SDN-лист (Specially Designated Nationals and Blocked Persons), накладывающий ограничения на сотрудничество с ним граждан США и американских компаний. Вскоре российский лидер производства алюминия предупредил о возможности технического дефолта, рейтинговым агентством «Фитч» были отозваны кредитные рейтинги компании.

При полномасштабном применении санкций США в отношении активов российского олигарха, их заморозке в американских банках, полном запрете для американских структур на ведение бизнеса с компаниями из санкционного списка и вторичных санкциях для нерезидентов США за сотрудничество с компаниями олигарха резко снизилась выработка алюминия, поставляемого на американский рынок, и рынки стран, зависящих от «опеки» США - прежде всего Японии. Сокращение объемов производства алюминия отрицательно сказалось бы на работе крупных предприятий региона и повлекло за собой задержку заработной платы, сокращение персонала, заморозку проектов развития. Была проведена оценка влияния санкций на «РУСАЛ», производство алюминия в 2018 г. могло сократиться на $30 \%$ от бизнес-планов компании в основном сценарии и на 50-70 \% - в случае сохранения отрицательной динамики [4]. 
Параллельно произошло бы увеличение стоимости произведенной продукции, а это значит, что конкурентные позиции российской компании на рынках, не затронутых заокеанскими санкциями, могли быть существенно ослаблены. Негативный сценарий мог затронуть жизнедеятельность моногородов региона, в которых крупные предприятия являются гарантами стабильности и перспектив развития. Таким образом, санкции, инициированные из-за океана, ударили бы по социально-экономической обстановке континентального региона РФ - Иркутской области. Компании все же пришлось отказаться от ряда социальных проектов, так, не был реализован планировавшийся в мае 2018 г. проект второго международного книжного фрестиваля в столице Восточной Сибири - «Иркнига». Журналист инфрормационного агентства «Рейтерс» Э. Хоум написал панегирик в отношении санкционного давления в отношении российских компаний «Этот алюминиевый бумеранг пролетел от острова Джерси, где «Русал» зарегистрирован, через предприятия в Ирландии, Швеции до сердца России. Вопрос только в том, на кого будет направлен следующий удар» [5].

Вместе с тем, угроза масштабных американских санкций в отношении активов Олега Дерипаски, хоть и вызвала бурю на фринансовых рынках и привела к частичной потере капитализации вышеуказанных бизнес-структур на мировых биржах, носила характер преимущественно информационного шторма, влияние которого на российский бизнес оказалось незначительным. Основной причиной этого стало уточняющее заявление Министерства финансов США о том, что санкции с «РУСАЛА» и прочих активов могут быть сняты в том случае, если Олег Дерипаска прекратит являться основным бенефициаром своих компаний и выйдет из контроля над вертикально интегрированными холдингами.

Сложная ситуация и санкционное давление американской стороны вынудило российского олигарха покинуть советы директоров структур «РУСАЛа» и En+ Group. Падение капитализации российского алюминиевого гиганта на зарубежных биржах способствовало тому, что руководство энергетической структуры и En+ Group решило компенсировать выпадающие доходы за счет жителей Иркутской области, сделав заявление о грядущем повышении тарифов на электроэнергию для населения региона, мотивировав его тем, что жители региона пользуются самыми низкими энергетическими тарифами на территории РФ [3]. Таким образом, внешнеэкономический санкционный фрактор стал элементом не только фредеральной, но и внутри-региональной политической повестки, тема повышения тарифов активно использовалась в рамках предвыборной кампании 2018 г. в Законодательное собрание Иркутской области, появилось движение «СТОП Тариф», дивиденды от деятельности которого получали депутаты от КПРФ. Губернатор С.Г. Левченко заявил о необходимости дополнительных переговоров с Олегом Дерипаской по этому вопросу [4]. Депутаты региона в Государственной Думе от «Единой 
России», в частности, С. Тен, стали делать заявления о том, что потери структур «системного» олигарха будут компенсированы федеральными властями, которые не заинтересованы в ухудшении социально-экономической обстановки в регионе [4]. Таким образом, фрактор санкционной политики, удар по российскому экономическому капиталу был сразу же конвертирован на политическом рынке и использован для повышения политического капитала региональных политиков, действующих на федеральном уровне. Стала рассматриваться возможность закупки государством алюминия, производимого «РУСАЛом» - для долгосрочного хранения продукции на складах и сохранения объемов производства.

В итоге санкции США повлияли на «РУСАЛ», но, так как они вводились не в полном объеме, прибыль корпорации снизилась в 2018 г. на 31 \% по сравнению с первым кварталом 2018 г. до 218 млн дол. США [2]. На 19 \% снизился объем реализации алюминия. Значительных сокращений сотрудников предприятий Олега Дерипаски удалось избежать, соответственно, санкции не повлияли на социально-экономическую обстановку в моногородах Иркутской области.

В силу каких причин санкции США не были введены в действие в полном объеме и действовали ограниченный промежуток времени? Возможный ответ связан с тем, что бизнес-активы Олега Дерипаски включены в систему мирового разделения труда, участвуют в экономической глобализации.

В 2017 г. «РУСАЛ» произвел 3,7 млн т алюминия, на внутрироссийский рынок ушло порядка 650 тыс. т «авиационного металла», остальной объем произведенной продукции первого передела был реализован на внешних рынках. Так, основной объем поставок алюминиевого концерна приходится на страны Европейского союза - 42 \%, на азиатских рынках продается $17 \%$ произведенного алюминия, в России и СНГ реализуется 24 \% продукции, в то время как в Соединенные Штаты Америки уходит 10 \% алюминия «РУСАЛа» [5]. Таким образом, поставки в США являются для российской компании важным ресурсом получения валютной выручки.

А в США основными потребителями качественного и дешевого российского алюминия являются автопром и авиационная промышленность, которые в условиях напряженных торгово-экономических контактов с КНР заинтересованы в диверсификации поставок производственного сырья.

Таким образом, уже в декабре 2019 г., после того, как Олег Дерипаска снизил свою долю в компании $\mathrm{En}+\mathrm{Group}$, Минфин США решил снять санкции со структуры UC Rusal [1; 7]. При этом условием снятия ограничительных санкций была схема, по которой $25 \%$, на которые Олег Дерипаска уменьшил свой пакет в En+ получит структура, которая не находится в санкционном списке SDN. При этом Министерство финансов США получит возможность проверок связей $\mathrm{En+}$ и «РУСАЛа» с рос- 
сийским олигархом, En+ и AO «Евросибэнерго» следует предупреждать Минфин США на ежемесячной основе о том, что они не действуют в интересах лиц из списка SDN. Тем не менее, в конгрессе США была принята символическая резолюция против снятия санкционного давления c En+ Group и «РУСАЛ», в которой отмечалось, что «Конгресс не одобряет действий, связанных со снятием санкций, введенных в отношении группы En+, UC Rusal и AO «Евросибэнерго» [8].

Таким образом, позитивным фактором, способствовавшим достаточно оперативному выходу корпораций российского бизнесмена изпод западных санкций, являлась частичная вовлеченность российской производственной и энергетической корпорации в глобализированные потоки, и заинтересованность американской промышленности в российском алюминии.

В январе 2019 г. санкции США вновь проявили себя в отношении еще одной российской корпорации, действующей на территории Иркутской области. На этот раз под санкции попал перспективный проект «Ростеха» и Объединенной авиастроительной корпорации - среднемагистральный самолет «MC - 21», планируемый к серийному производству на Иркутском авиазаводе с 2020 г. [6]. Запуск серийного производства «МС-21» на территории Иркутска означал бы появление новых рабочих мест, развитие смежных производств.

Влияние американских санкций проявилось в запрете поставок материалов компаний «Хексель» (США) и «Торай Индастриз» (Япония), необходимых для композитного крыла российского самолета, являющегося ключевым конкурентным преимуществом отечественного проекта над американским «Боинг» и европейским «Эйрбас» [6]. Оставшегося на российских заводах запаса импортных композитов хватит только на шесть месяцев. Использование аналогичных композитов производства КНР затруднительно по причине недостаточных конструктивных характеристик, а создание российских композитов потребует дополнительных опытно-конструкторских разработок, что значительно удлинит сроки серийного производства «МС-21», но вместе с тем создаст новые технологические заделы на территории России.

Таким образом, санкции США выступают в качестве полноценного инструмента конкурентной борьбы с высокотехнологичными российскими разработками, которые в перспективе могут создать существенную конкуренцию основным игрокам зарубежного авиапрома.

Резюмируя вышеизложенное, следует отметить, что факторы санкционного давления оказывают непосредственное влияние на внешнеэкономические связи предприятий вертикально интегрированных холдингов, расположенных на территории Иркутской области. В некоторых случаях (ситуация с активами О. Дерипаски), российские корпорации, выпускающие продукцию первого передела, могут относительно быстро 
выйти из-под санкционного давления, выполнив ряд условий. Такого рода санкции носят «фантомный» характер, вызваны текущей внешнеполитической конъюнктурой, их негативный эффект может быть сравнительно легко нивелирован. В то же самое время, высокотехнологичные корпорации, способные выпускать конкурентную продукцию, фактически лишаются необходимых для производства компонентов, что сказывается на сроках выпуска продукта и негативно влияет на развитие региона в среднесрочной и долгосрочной перспективе.

\section{Список использованной литературы и источников}

1. Бурмистрова C. Rusal на свободе: что будет с компанией после отмены санкций США [Электронный ресурс] / С. Бурмистрова, А. Филипенок // РБК. 2019. - 28 янв. - Режим доступа : https://www.rbc.ru/business/28/01/2019/ da63c4bc8

2. Васильева Д. Перейдет ли энергетика Иркутской области в чужие руки [Электронный ресурс] / Д. Васильева // Ирк.ру. - 2019. - 26 февр. - Режим доступа : https://www.irk.ru/news/articles/2026/aluminium/

3. Дятел Т. Олег Дерипаска ждет поддержки граждан [Электронный ресурс] / Т. Дятел, А. Джумайло, Е. Еременко // Коммерсантъ. - 2019. - 10 янв. - Режим доступа : https://www.kommersant.ru/doc/3642540

4. Палько В. Чем обернулись санкции и контрсанкции для Иркутской области [Электронный ресурс] / В. Палько // Ирк.ру. — 2018. - 14 июня. - Режим доступа : https://www.irk.ru/news/articles/sanctions/

5. Санкции против «Русала»: кому это выгодно [Электронный ресурс] // Газета.ру. - 2018. - 16 апр. - Режим доступа : https://www.gazeta.ru/ business/2018/04/16/updated (дата обращения: 01.02.2019)

6. Синергиев И. Санкции махнули черным крылом [Электронный ресурс] / И. Синергиев, Г. Костринский, В. Дзагуто // Коммерсантъ. - 2019. - 10 янв. Режим доступа : https://www.kommersant.ru/doc.main_1

7. США отменили санкции против компаний «Русал», En + и «Евросибэнерго» [Электронный ресурс] // Ирк.ру. - 2019. - 28 янв. - Режим доступа : https:// www.irk.ru/news/20190128/sanctions/

8. Disapproving the President's proposal to take an action relating to the application of certain sanctions with respect to the Russian Federation [Electronic resource] // $116^{\text {th }}$ Congress $1^{\text {st }}$ Session. - 2019. - 15 January. - URL : https://www. congress.gov/ 116/bills/hjres30/BILLS-116hjres30ih.pdf

\section{Информация об авторе}

Олейников Илья Васильевич - кандидат исторических наук, доцент, кафедра политологии, истории и регионоведения, исторический фракультет, Иркутский государственный университет, 664003, г. Иркутск, ул. Чкалова, 2; e-mail: oleynikov@isu.ru

\section{Author}

Ilya V. Oleynikov — PhD in History, Associate Professor, Chair of Political Science, History and Regional Studies, History Faculty, Irkutsk State University, 2 Chkalov St., 664003, Irkutsk, Russia; e-mail: oleynikov@isu.ru 